\title{
Progressive Technologies in Design of Town Planning and Landscape Recreational Objects Made of Floating Modular Elements
}

\author{
Nadiia Shebek ${ }^{1}$, Oleksandr Olkhovets ${ }^{2}$ \\ Kyiv National University of Construction and Architecture \\ Povitroflotsky avenue 31, Kyiv, Ukraine, 03037 \\ 11n-sh@ukr.net, orcid.org/0000-0001-6038-3945 \\ 2sanja ol@ukr.net, orcid.org/0000-0001-9885-8723
}

Received 05.04.2019, accepted after revision 16.06.2019 https://doi.org/10.31493/uwt1909.1901

\begin{abstract}
The article outlines the major research areas on the problem of the water area exploitation in town planning, as well as progressive trends in the design of floating residential, public, production, recreational buildings and facilities. The latter include the forming of aquatorial spatial structures, such as floating town planning and landscape recreational objects.

It has been acknowledged that man-made archipelagos are feasible to be assembled of unified modular elements produced in a big number of copies by industrial enterprises, which implies their high quality and relatively low cost. Such elements are transported to their location of use through waterways, which makes their shipment significantly cheaper. During the operation, floating structures, if necessary, are capable of changing their function, size, configuration and location. Their damaged elements can be quickly substituted with the new ones, while unsuitable for further use fragments may be adjusted to other needs or recycled.
\end{abstract}

Floating modules must meet specific requirements that apply to mobile buildings and facilities. Among them, the requirements of technological effectiveness of production, transportation efficiency, autonomous operation, adaptation to extreme operating conditions. In addition, expectations for their reliability, efficiency and environmental friendliness are increasing.

In order to program the life cycle of floating town planning and landscape recreational objects it is suggested to use progressive technologies of building information modeling. BIM-technologies are an efficient means of collective creation, processing and storage of information for the whole

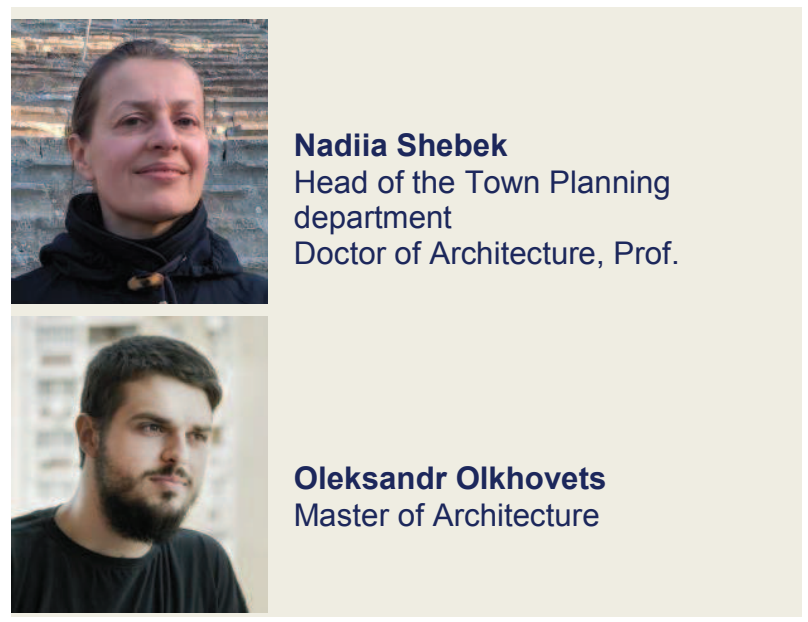

lifecycle object. Their use has a positive effect on the indicators of efficiency, performance, cost and safety of construction, logistics and operation of the object. The use of BIM-technologies avoids most of the errors at the design stage and make the necessary corrections during the implementation of the intention. The principle of parametricity, realized in the BIM-environment, influences all the sections of the draft, which to some extent guarantees accuracy in the development of a design solution.

Keywords: floating modular elements, town planning and landscape recreational objects, technologies of building information modeling.

\section{INTRODUCTION}

Since ancient times, people settled near rivers, lakes, seas and oceans. The increase in the number of coastal cities' inhabitants gradually 
led to overpopulation. In the search of new living space nearby traditional places of civic engagement, their inhabitants built artificial embankments and islands, settled on redeveloped vessels in town canals, fabricate pontoon buildings and structures, that is, water surfaces have been colonized in various ways.

Discouraging prospects of the ocean level rise due to global warming imply the flooding of existing settlements, which will lead to losing a considerable number of places of residence during the next decades. The probable threat only accelerates the rate of coastal areas urbanization.

Contamination of world's waters with an incredible amount of waste is becoming an urgent challenge for the global community. It causes the need for floating waste recycling enterprises, capable of coping with the litter islands drifting in the oceans, as well as with microplastic and other hazardous substances which threaten the existence of various water bodies' flora and fauna. These kinds of garbage, like all other, can be considered as the sources of raw materials and energy for the construction and operation of sanation floating settlements.

Humanity is attracted to other, previously unattainable, ocean resources. In particular, there is a reason for the construction of industrial-mining complexes, aimed at finding and extracting useful substances from the water and bowels of the earth.

Recreational complexes located on and under the water address different tourists' needs, including diving, passive recreation and sanitation on the water surface, extreme activities with the use of various water craft etc.

Neutral waters can shelter people who are eager to isolate themselves from the society. In floating sociopolises, unrestricted by certain countries' legislation, volunteers can conduct social experiments on innovative ways of social organization.

Finally, the absolute majority of the water spaces of the planet is still unexplored. Thus, there is a need for research stations, which would allow to constantly monitor the life of the oceans while living in comfortable conditions directly at the places of research and changing location in accordance with the natural movement of ocean currents.

Problems relating to the overpopulation of the shores, the threat of coastal areas flooding, the ocean water contamination, hope for getting the access to new sources of various resources, craving for adventures and innate curiosity urge the society to master the water. Scientific progress and the rapid build-up of technological potential have made the longcherished dream of humanity achievable. As a result, designers of various specialties face the task of developing realistic mechanisms for penetration into a new, previously uninhabitable aquatic environment.

\section{ANALYSIS OF PREVIOUS STUDIES}

Many futurologists consider water space as the most promising location for the development of new settlement forms [1-3]. Urbanization of water areas is gaining more and more supporters among scientists [4-8] and practicing architects [9-11] every year. Ukraine has quite large water bodies, therefore scientists of the country reflect on the problems and prospects of river, lake and reservoir development [12-15], while young Ukrainian architects suggest alternative ways of water spaces use [16-18]. These researches confirm the relevance of the chosen topic, define the strategic goal of water areas urbanization and describe the tasks which must be solved to achieve it.

The history and current trends in the design of mobile buildings and structures are discussed in works [19-23]. Progressive technologies of design and life management of architectural and urban objects are described in the works $[24,25]$. Statistics on the use of prefabricated objects from modular elements is presented in the study [26]. The results of these studies are useful for developing efficient methods of design, produce and operation of aquatorial spatial structures.

In this study, it is first proposed to combine the most interesting of these ideas in order to outline the main areas of programming the life cycle of town planning and landscaperecreational objects from floating modular elements. 


\section{RESULTS AND DISCUSSION}

In the modern world, the practice of using floating buildings and structures of various purposes is quite common. Such objects are of interest primarily because of their singularity, however, they have more significant advantages as compared with the ground-based, both stationary and mobile architectural creations. For example, the problems of land lease do not disturb their owners. They are not burdened with the preparation of bases and the construction of foundations. Powerful vehicles are not needed to move the buildings on pontoons. The efficiency of energy production from renewable sources increases on the water surface. It is more comfortable for people to withstand the summer heat near the water. A wide range of entertainment is associated with water. Contemplation of water soothes and creates prerequisites for restoration of emotional balance. Beautiful landscapes are always surrounded by mobile artificial islands. The water bodies themselves attract a human's eye, so any architectural creations on their surface automatically fall into the center of universal attention.

These and other positive features of aquatic architectural objects testify to their extraordinary town planning and landscape recreational potential, which today is not used to the full extent. In particular, predominantly single monofunctional floating formations operate in different parts of the world. Most of them are privately owned and have little effect on the lives of local people. However, many proposals on the organization of significant in size and complex in design water spatial structures have been developed at the conceptual level. Among them, aquapolis, temporary settlements for migrants, floating recreational complexes and so on.

This year, students of the Town planning department of KNUCA explored two in principle new directions for the use of floating buildings and structures. In I.V. Basak's master's thesis, the feasibility of widening the public areas of coastal towns at the cost of interconnected aquatorial structures capable of changing their location in accordance with the season, current needs of the residents and specific conditions is well founded. The main theoretical foundations of the work are realized in the project of the floating islands complex on the Dnipro River in the city of Kyiv (Fig.1). In K.S. Balanda master's thesis, it is suggested using mobile floating modules for tourist services on the floating routes along plain rivers and developed two types of recreational units for short and long stay on the tourist route along the Desna River in Chernihiv region (Fig.2). In both cases, it is suggested to create town planning and landscape recreational aquatorial megastructure capable of flexible reaction to the needs of visitors and operating conditions.

Water spatial structures, such as floating town planning and landscape recreational objects, are formed through a purposeful combination of numerous mobile buildings and structures of various purposes. For the production aquatorial megastructures it is feasible to use mountable-dismountable modular units. The application of highly productive methods of their manufacture, implementing the logical sequence of operations, the use of unified elements and joints allows to shorten the time of floating structures' elements production, minimize expenditures and provide the high quality of a final product.

It is necessary to strive for the most rational use of space in floating town planning and landscape recreational objects. For example, instead of designing floating parks, one should consider roofs and facades greening and buildings on pontoons.

The safe operation of floating modular structures can be achieved through dividing them into sealed compartments. Special attention should be paid to the basements of floating structures. The use of pontoons allows locating floating objects in areas with changeable water level. Floating modules can be equipped with self-retracting piles capable of cutting into the bottom automatically. The system of anchors can also be used.

Another important issue is the design of constructive systems which allow to stabilize modules on water surface and provide appropriate rigidity, hardness and the tightness of 


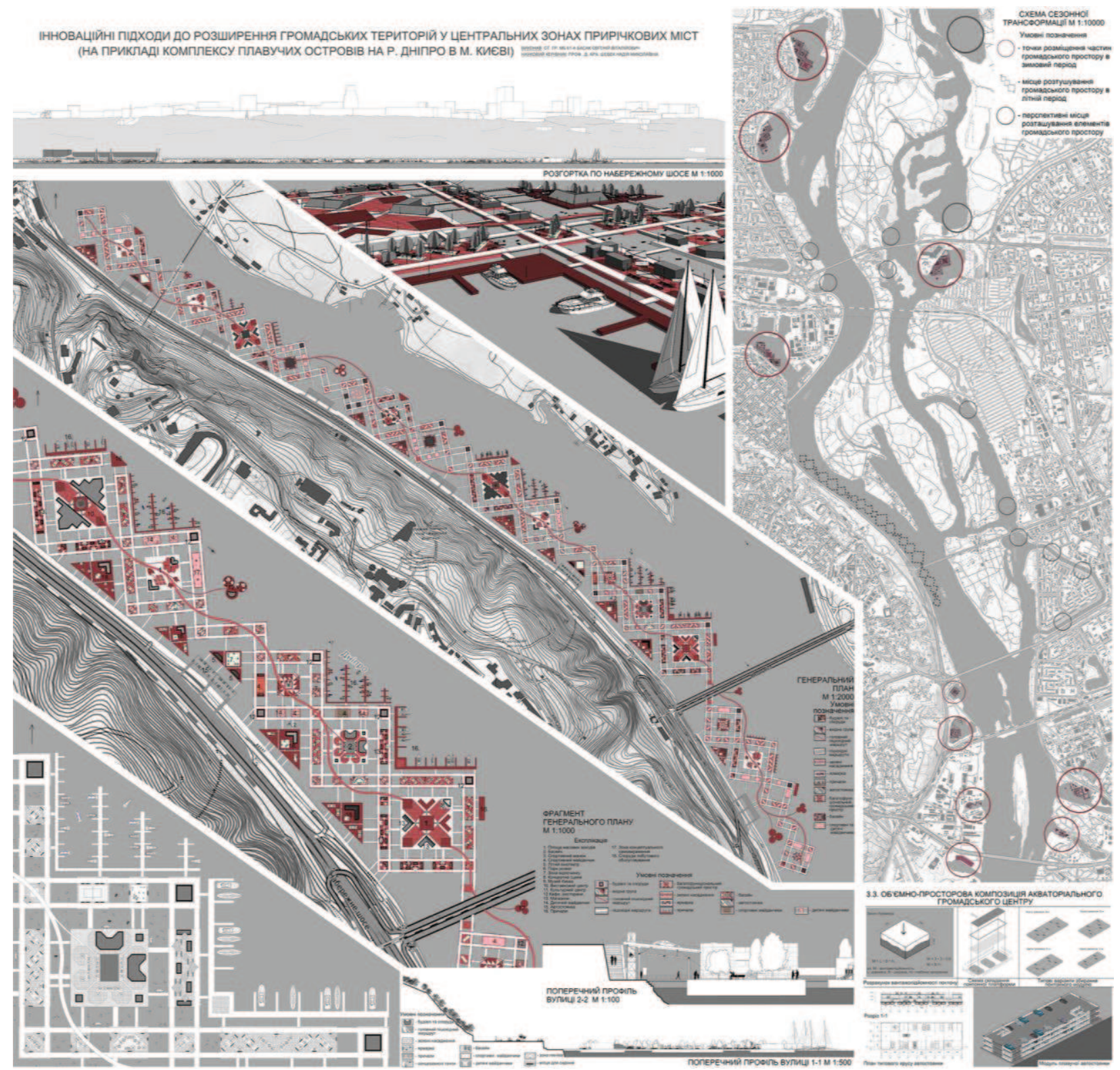

Fig.1. The project of the floating islands complex on the Dnipro River in the city of Kyiv, student I.V. Basak, head Professor N.M. Shebek: 1 - scanning along Naberezhna Highway, 2 - master plan, 3 - fragments of the master plan, 4 - seasonal transformation scheme, 5 - transverse street profiles, 6 - floating modules

structure under the conditions of severe frost, ice drift, hard wind, storms, thunders and other extreme weather conditions.

The mechanisms of floating modules' adaptation to the changes in operation conditions through the transformation of a floating archipelago's general configuration and the changes in separate fragments' functions have to be foreseen in advance. Much attention should be paid to the programming of utilization, recycling and secondary use of modules methods.
While developing aquatorial spatial structures one has to consider both productive and operating requirements. For instance, the minimization of separate modules' size will allow rationalizing the process of their transportation. The compactness of floating spatial structures' forms will lead to the shortening of distances between their main elements and improve the comfort of visitor. The maximum use of natural lighting will result in the expenditures on electricity reduction. 


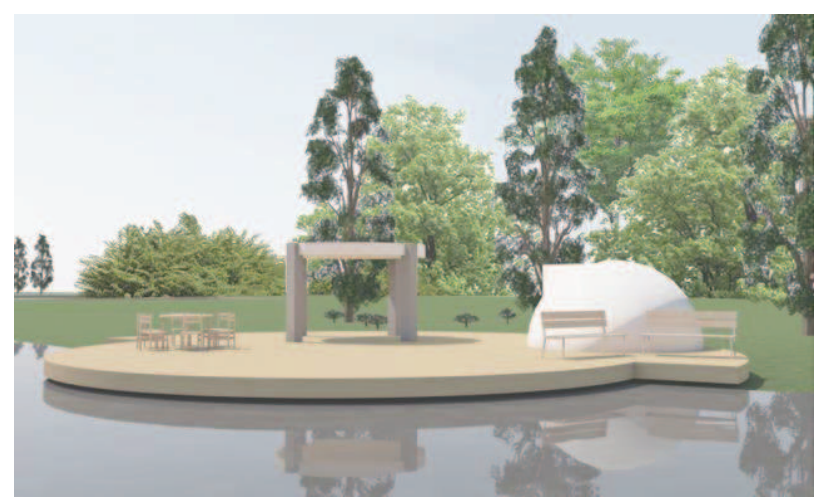

$a$

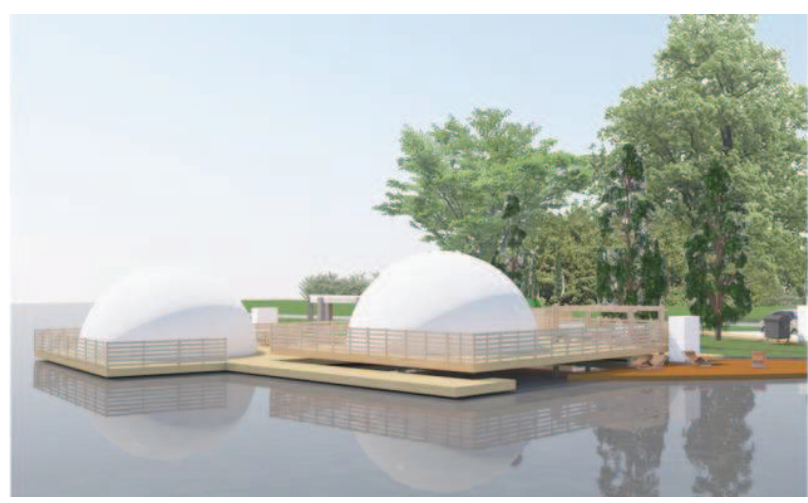

$b$

Fig.2. Project of recreation modules on the tourist route along the Desna River in Chernihiv region: $a$ - for short stay, $b$ - for long stay, student K.S.Balanda, heads Professor N.M. Shebek, Associate Professor M.E. Tretiak

Floating modular structures should be characterized by high resource efficiency. Buildings on pontoons can be organized on the principle of a passive house, made of sustainable and climate-resistant materials, equipped with devices for water reuse. Installations for the composting of household waste should function there. Meanwhile, it is necessary to make any negative influence of artificial objects on natural environment impossible.

The key task of designing floating modular objects is the possibility of obtaining resources from the external environment. First of all, it is water resources, wind and solar energy.

Floating structures should be equipped with rainwater collection facilities, filtration and refinery devices for the use of freshwater or desalination plants in the event of the placement of an aquatic settlement in seas and oceans. It is necessary to use heat pumps for heating the floating structures. There is a possibility of integrating solar panels, portable wind and hydropower plants into aquatorial structures. In this case, the production of wind and solar energy is particularly effective, since floating islands are open to all winds and have a large area, and solar panels on the modules' roofs of the are not overshadowed.

Rapid technological progress has positively influenced the development of all spheres of human activity, including construction and architecture. New methods of architectural and engineering design of buildings and structures have appeared, the quality of the final product has grown, and the risks of the participants in the construction process have partially decreased. The negative impact of the human factor has been reduced thanks to technologies that minimize the likelihood of making mistakes in design and construction. The productivity of the construction industry has undergone growth due to the gradual development of two digital technologies, namely:

- digital automation of product development and product manipulation, including the of use computer numerical control equipment (CNC) and the introduction of automated design systems (CAD);

- digital integration of information exchange processes in 3D models of architectural objects, or building information modeling (BIM).

The use of the latest information technologies' potential by developers, manufacturers and consumers of floating town planning and landscape recreational objects promises a significant socio-economic effect. CNC machines allow performing actions that are expected of them with absolute precision. The use of $\mathrm{CNC}$ at the production stage is an effective method of manufacturing and assembling the elements of the modules, especially in cases when it is necessary to achieve tightness of the connections and completely eliminate errors caused by the human factor. Building information modeling is an efficient means of accumulating and using of a huge amount of various data on architectural and town planning facilities at 
all stages of their existence by all interested parties.

The building information model can be described as a three-dimensional virtual model of an architectural and town planning object, supplemented with data on all stages of its life cycle. In the process of creating such a model the tasks of the customer, the existing standard requirements for a specific type of buildings, construction conditions are taken into account. All the necessary information about building materials, products and constructions, engineering systems and security systems, and other data, which allows the final product to be more efficient, is entered into a model.

BIM-technologies are based on the principles of parametric modeling. Changing the parameter of one element automatically causes a transformation of the structure as a whole, since, for example, the load from the changed element will not remain the same, which will affect the calculated model. Therefore, BIMtechnologies will allow into interconnect all the components of each floating spatial structure in the virtual environment, regardless of their physical location.

Thanks to the joint use of one model by all participants of the design process, their cooperation becomes more comfortable and its efficiency improves. Architects' productivity increases, contractors can reduce construction time and expenditures, and owners can quickly make suggestions and comments, and get a response in real time.

Floating modular structures may be selfmovable or transported by means of transport. The methods of their transformation include unplugging and connecting the modules, protruding, rotation and displacement of the module's parts along the guides, removing the partitions.

The information on the logistical operations is entered into the building information model of any aquatic structure, which allows calculating economical effect, possible expenditures and negative consequences efficiently and precisely.

Another task is to develop the diagnostic methods for the state of artificial islands and environmental parameters. Modules must be equipped with temperature, moisture, oxygen, pressure and other sensors, etc. The sensors should be connected to the system which controls and manages the processes of living environment's adaptation of to the environmental parameters.

Information modeling of processes gives an opportunity to foresee problems during the construction and operation of objects, to realize their influence on the schedule of works and to find the best ways of correction of the situation. The benefits of such an opportunity are evident for mobile settlements that will function in the oceans at considerable distances from civilization.

The high level of production automation, as well as constant monitoring and maintenance of the floating structures' operational parameters due to the integration of digital technologies into the physical space will reduce the likelihood of production or management problems caused by the negligence or the lack of competence of a specific employee.

Finally, BIM technologies can be used for automated control of fully robotized floating modular production complexes, the main purpose of which will be the removal of plastic waste from the water objects and its recycling into raw materials needed for the production of floating modules.

The operation of such structures can be imagined as a continuous process, which begins with the collection, sorting, chemical and mechanical processing of plastic rubbish with the aim of its purification and shredding. An intermediate stage in the processing of secondary raw materials is the manufacture of plastic granules, from which it is possible to manufacture plastic products further by pressing or extruding them into separate final products, or processing into fibers or using granules themselves as filler for a specific shipbuilding concrete.

The final stage of the production process may be the manufacturing of floating modules, equipment for them, and household items for the residents of floating villages, advertising products and branded goods.

The addition of recycled polyethylene terephthalate (PET), which is currently widely 
used for the production of packaging materials and is actively polluting the environment, in the compound of composites positively affects the performance of the latter.

Such production does not require the immediate involvement of a person, and therefore can be completely robotic. This approach to production will allow creating industrial pontoon structures that will be able to produce new pontoons from the non-refined rubbish with minimal use of new resources.

The introduction of BIM-technologies in architectural and urban planning practice creates prerequisites for the development of advanced projects, the use of effective methods of their implementation and operation. The future of modular constructions depends largely on the development of BIM-technologies. The implementation of modern digital methods can also positively affect the spread of town planning and landscape recreational objects made of floating modular elements.

\section{CONCLUSIONS AND PROSPECTS OF FURTHER RESEARCHES}

The research on previous studies showed a steady increase in the scientists' interest in the problems of water areas urbanization. The number and typological diversity of objects that successfully operate in fresh and saltwater areas, in settlements and beyond them is increasing every year. These are residential, public, industrial buildings and structures, artificial recreation spaces, transport and engineering structures.

Floating town planning and landscape recreational objects have many common features with mobile buildings and structures, so they must fully meet the specific requirements that are imposed on them.

At the same time, the constant contact with water certain features into the processes of their design, manufacturing, operation, maintenance, renovation and utilization. In particular, the requirements for their reliability, autonomy, compliance with the most stringent environmental standards are increasing.

All this leads to the expediency of application building information modeling advanced technologies in the programming process of the floating town-planning and landscape- recreational objects' life cycle. BIMtechnologies increase the efficiency of the processes of creating, processing and accumulating information about floating structures; increase efficiency, productivity and safety of construction, reduce production, logistics and operating costs, and avoid many errors at the design and implementation stages of the design intent.

The priority development directions of the floating town-planning and landscaperecreational objects in Ukraine include the research laboratories' network formation that will explore the problems and methods of natural and artificial reservoirs and watercourses rehabilitation; additional territories creation for mass events carrying out and inhabitants' in coastal settlements communication; recreation and sanitation centers organization in conditions of direct interaction with the healing precious environment.

A significant socio-economic effect will be achieved provided an architect's rise of creative imagination in combination with advanced engineering developments, precise calculations and leading informational technologies. It can be used in various spheres of society's life due to modest value, high quality and mass production of modular elements, of which should consist of floating town-planning and landscape-recreational objects. Reducing the "human factor" weight at each stage of such objects` life cycle significantly increases its reliability.

Autonomy, environmental friendliness and mobility of such architecture allow it to be used effectively in the historic urban environment, as well as in remote places of civilization without any harm to the environment. Significant variability of the volume-spatial solutions of individual modules and the unlimited combinatorial decisions of structures made of them will preserve the artistic expressiveness of such objects.

\section{REFERENCES}

1. Velev P. S., 1985. Cities of the Future. Stroyizdat, 160 (in Russian).

2. Танге K., 1976. The Architecture of Japan. Tradition and Modernity. Progress, 239 (in Russian).

3. ArchiLab's Urban Experiments: Radical Architecture, Art and the City, 2005. Thames \& 
Hudson, Mori Art Museum, 368.

4. Shebek N. N., Chernyatevich N. G., 2015. The Main Directions of Research the Problem of Urban Development of Water Areas. Trudy mezhdunarodnoj nauchno-prakticheskoj konferencii Arhitektura i stroitel'stvo Kazahstana v uslovijah global'noj integracii. KazNTU im. K.I. Satpaeva, 146-150 (in Russian).

5. Sadykov M.O., 2009. Conceptual Modelling of a Floating City. Arhitekton: Izvestija vuzov, UGAHU, Vyp.26, 8 (in Russian).

6. Smirnova O.V., 2016. Water Devices as Means of Formation of Innovative Nature Integrated Buildings in Urban Environment. Komunal'ne gospodarstvo mist. Serija: Tehnichni nauki ta arhitekturi. Vyp.132, 25-30 (in Russian).

7. Rodina O. A., 2016. Features of Architectural and Typological Formation of Landing Stages (on the Example of the Volga-Kama Basin). Dis. ... kand. arh. 05.23.21 - Arhitektura zdanij i sooruzhenij. Tvorcheskie koncepcii arhitekturnoj dejatel'nosti. NGASU, 200 (in Russian).

8. Ekonomov I. S., 2010. Principles of Formation of Low-rise Residential Buildings on the Water: avt. dis. ... kand. arh. 05.23.21 - Arhitektura zdanij i sooruzhenij. Tvorcheskie koncepcii arhitekturnoj dejatel'nosti, MARHI, 37 (in Russian).

9. Basak I. V., 2019. Theoretical Prerequisites of the Location of Urban Public Centers in Water Areas. Regional'na politika: istorija, politikopravovi zasadi, arhitektura, urbanistika, Vyp.IV, Ch.1, 156-159 (in Ukrainian).

10.Ruban L., 2016. Underwater Urban Studies: Modern Issues and Trends. Underwater Technologies, Vol.03, 54-65 (in Ukrainian).

11.Gryshyn V., Gembarskyi L., Snisarenko V., 2015. Existing and Projected Artificial Islands and their Purpose. Underwater Technologies, Vol.02, 32-39 (in Ukrainian).

12.Kushnirenko M., 2009. Problems of Urban Using Coastal Areas of the Dnipro Reservoirs. Dosvid ta perspektivi rozvitku mist Ukraiini, Vyp.17, 94-113 (in Ukrainian).

13.Chernyatevich N. G., 2016. Floating Bases of Aquatorial Settlement. Suchasni problemi arhitekturi ta mistobuduvannja, Vyp.46, 351356 (in Ukrainian).

14.Shebek N. M., Chernyatevich N. G., 2015. Prospects for the formation and development of aquatorial settlement systems in Ukraine. Dosvid ta perspektivi rozvitku mist Ukraiini, Vip.29, 94-105 (in Ukrainian).

15.Shebek N. M., Dragomirova G. A, 2017. Urban Development Potential of Water Bodies and Adjacent Territories. Regional'na politika: istorija, politiko-pravovi zasadi, arhitektura, urbanistika. Beskidi, Ch.2, 19-24 (in Ukrainian).

16.Shebek N. M., 2016. Perspective directions of water areas urbanization. Suchasni problemi arhitekturi ta mistobuduvannja, Vyp.46. 356361 (in Ukrainian).

17.Balanda K. S., 2019. Architectural-planning Organization of the Rafting Route along the River Desna in Chernigiv Region. Mistobuduvannja: problemi i perspektivi rozvitku, KNUBA, 26 (in Ukrainian).

18.Basak I. V., 2019. Prospects for the development of innovative communities on the waters in the central zone of Kyiv. Mistobuduvannja: problemi i perspektivi rozvitku, KNUBA, 27-28 (in Ukrainian).

19.Gajduchenja A. A., 1983. Dynamic Architecture: Main Directions of Development, Principles, Methods. Budivel'nik, 96 (in Russian).

20.Saprykina N. A., 2005. Basics of Dynamic Morphogenesis in Architecture. Arhitektura-C, 312 (in Russian).

21.Shemsedinov G. I., 2007. Designing Mobile Buildings. KNUBA, 144. (in Ukrainian)

22.Gorbatenko E., Bratasyuk I., Sharov V., 2015. Mobile building is in coastal hydraulic engineering. Underwater Technologies, Vol.01, 23-32 (in Ukrainian).

23.Smith R. E., 2010. Prefab Architecture: a Guide to Modular Design and Construction. New Jersey, 402.

24.Salman Azhar, Abid Nadeem, Johnny Y.N. Mok, Brian H. Y. Leung, 2008. Building Information Modeling (BIM): A New Paradigm for Visual Interactive Modeling and Simulation for Construction Projects. First International Conference on Construction in Developing Countries (ICCIDC-I). Advancing and Integrating Construction Education, Research \& Practice.

25.Ratti K., Klodel M., 2018. City of Tomorrow: Sensors, Networks, Hackers, and the Future of Urban Life. Izd-vo inst-ta Gajdara, 248 (in Russian).

26.Keith F., 2011. Prefabrication and Modularization: Increasing Productivity in the Construction Industry, 56. 


\section{Прогрессивные технологии проектирования градостроительных и ландшафтно- рекреационных объектов с плавучих мо- дульных элементов}

\section{Надежда Шебек, Александр Ольховец}

Аннотация. Рассмотрены основные направления исследований проблемы градостроительного освоения акваторий, а также прогрессивные тенденции проектирования плавучих зданий и сооружений жилого, общественного, производственного и рекреационного назначения. К последним отнесены формирование значительных по размеру и сложных по строению акваториальных пространственных структур плавучих градостроительных и ландшафтнорекреационных объектов.

Признано, что искусственные архипелаги целесообразно собирать из унифицированных модульных элементов, которые изготавливаются большими тиражами на промышленных предприятиях, что обуславливает их высокое качество при относительно низкой стоимости. Они транспортируются к местам использования водными путями, что позволяет существенно удешевить их перемещение в пространстве. В процессе эксплуатации, при необходимости, плавучие структуры способны изменять функциональное назначение, размер, конфигурацию и местоположение. Их поврежденные элементы могут быть быстро заменены новыми, а непригодные для дальнейшего использования фрагменты приспособлены для других целей или отправлены на вторичную переработку. Плавучие модули должны отвечать специфическим требованиям, предъявляемымк мобильным зданиям и сооружениям. Среди них - требования технологичности производства, эффективности транспортирования, автономности функционирования, приспособленности к экстремальным условиям эксплуатации. Кроме того, растут ожидания относительно их надежности, экономичности и экологичности.

Для программирования жизненного цикла плавучих градостроительных и ландшафтнорекреационных объектов предложено применять прогрессивные технологии строительноинформационного моделирования. ВИМтехнологии представляют собой эффективные средства коллективного создания, обработки и накопления информации в течение всего жизненного цикла объекта. Их использование положительно влияет на показатели оперативности, производительности, стоимости и безопасности строительства, логистики и эксплуатации объекта. Использование ВИМ технологий позволяет избежать большинства ошибок уже на стадии проектирования и вносить необходимые правки во время воплощения замысла. Принцип параметричности, реализованный в ВИМсреде, влияет на все разделы проекта, в определенной степени гарантирует точность при разработке проектного решения.

Ключевые слова: плавучие модульные элементы, градостроительные и ландшафтнорекреационные объекты, технологии строительно-информационного моделирования. 